\title{
Reflection on Ideological and Political Education in Colleges and Universities from the Perspective of Big Data*
}

\author{
Wenyan Feng \\ School of Marxism \\ Dalian Ocean University \\ Dalian, China
}

\author{
Zhaoyu Jiang \\ School of Marxism \\ Dalian Ocean University \\ Dalian, China
}

\begin{abstract}
Big data deeply affects and changes the mode and approach of ideological and political education, which challenges both the subjects and the objects of ideological and political education. It threatens the authority of the subject position of ideological and political education in colleges and universities, diversifies the ideology of the object of ideological and political education, and complicates the environment of ideological and political education in colleges and universities. But at the same time, it also brings opportunities: it will promote the optimization of ideological and political education of college students based on big data, such as personalized teaching, fined service and scientific management. Therefore, it is necessary to broaden the collection path of big data of ideological and political education, build a professional team of big data of ideological and political education in colleges and universities, improve the level of teacher information, and improve the teaching mode of ideological and political theory course in colleges and universities.
\end{abstract}

Keywords - big data; colleges and universities; ideological and political education

\section{INTRODUCTION}

The advent of the era of big data has posed the profound impact on all fields of today's society. The concept of "big data" generally accepted by the academic community is based on the elaboration of big data by Victor Mayer Schoenberg who is the author of the Big Data Era: "big data is a kind of value and methodology, what people are facing is not random samples, but all data; not accuracy, but hybridity; not causality, but correlation." While changing the society

*Fund: This paper is the phased achievements of youth fund program for humanities and social sciences of the Ministry of Education in 2016 "research on the expression and innovation of ideological and political education discourse in colleges and universities from the visual threshold of convergence media" (16YJC710008), fund program for humanities and social sciences of the Ministry of Education in 2017 "research on the innovation of ideological and political education mode in colleges and universities in the era of big data" (17YJA710005), undergraduate teaching reform program of regular higher education in Liaoning Province in 2018 "countermeasure research and practice of improving the discourse affinity of ideological and political theory course in colleges and universities", the teaching reform program of Dalian Ocean University in 2019 "research on the "trinity" teaching mode reform of ideological and political theory course in colleges and universities". and people's thought and behavior, big data also profoundly affects and changes the mode and way of ideological and political education.

\section{Challenges of Big Data to IDEOLOGICAL AND} POLITICAL EDUCATION IN COLLEGES AND UNIVERSITIES

In the era of big data, the authority of the subject status of ideological and political education will be threatened, the object ideology of ideological and political education will be more difficult to control, and the environment of ideological and political education is challenged, which brings great challenges to the ideological and political work in colleges and universities.

\section{A. Big Data Threatens the Authority of the Subject Status of Ideological and Political Education in Colleges and Universities}

The traditional ideological and political education is a kind of one dimensional education mode that is short of interaction. The subject of ideological and political education is the subject of transmitting information, and the object of ideological and political education is the object of receiving information. Educators will dominate what they say and teach and carry out teaching according to the sequence of knowledge. Generally, the object of ideological and political education does not have much autonomy and option. In the era of big data, ideological and political educators have their own ideas and data that needs to collected and analyzed according to a large number of various data and information transmission, diversity and transmission speed, so that the itself internal knowledge expressed by external data and ideological and political education complete knowledge system framework put forward some constructive opinions or suggestions, which will threaten the authority ideological and political education workers in colleges and universities.

First of all, due to the advancement of college students in the aspects of network skills and network culture, compared with the subjects of ideological and political education, they enjoy more professional science and technology in information collection, information mining methods, etc. In term of data analysis, they will also analyze and estimate the 
classroom. College students can download relevant data of ideological and political discipline, discuss scientific research results with teachers on the data platform, even put forward questions and answer and discuss the problems with teachers, which makes the classroom no longer the only position of ideological and political education. The data platform can also become a new position of ideological and political education, and even may become the main position in the future. and political educa it also makes educators at the end of their resources, and the authority of status is greatly challenged.

Finally, information asymmetry will seriously affect the effectiveness of ideological and political education work in colleges and universities. College students are a little more sophisticated than ideological and political educators in terms of network skills and network knowledge acquisition channels. Ideological and political educators are in the weak position in terms of information acquisition speed and quantity, which challenges the authoritative position of ideological and political educator subjects in colleges and universities.

\section{B. Big Data Makes the Ideology of Ideological and Political Education Objects in Colleges and Universities More Diversified}

The variety of big data is complicated and all-inclusive. On the virtual data platform, not all the data are unmistakable, which makes it more difficult for college students to choose the correct information resources and will cause the more or less changes of college students' values, outlook on life and world outlook. Some western countries' thoughts and ideas in big data may cause one-sided distortion of students' thoughts; some college students are easily induced and deluded by some negative and even antisocialist concepts; and some thoughts of money worship and hedonism also make an impact on the world outlook, outlook on life and values that college students are forming.

\section{Big Data Makes the Environment of Ideological and Political Education in Colleges and Universities More Complicated}

Against the background of big data era, the ideological and political education in colleges and universities has the following characteristics: first, the country is in a new era of rapid development and reform, and the formation of globalized society and "global village" makes all kinds of ideology emerge the world splendidly. With the help of data, college students' attention to social events and understanding of national policies are all liberalized and lopsided. Therefore, the new situation of the complexity of ideological and political education environment in colleges and universities puts forward unprecedented challenges to ideological and political educators. Second, big data has changed the space and time of ideological and political education in colleges and universities. Nowadays, the data technology changes with each passing day and provides quite convenient conditions for ideological and political education in colleges and universities. The space of ideological and political education is not limited to the

\section{BIG DATA BRINGS NEW OPPORTUNITIES TO IDEOLOGICAL AND POLITICAL EDUCATION IN COLLEGES AND UNIVERSITIES}

By relying on the construction of smart campus, and data mining and modeling technology, it can mine data and information related to students' behavior habits, learning characteristics, interest preferences, etc. on the basis of massive campus data. Combined with the goals of ideological and political education in colleges and universities, it can build models, establish prediction methods, and carry out trend analysis, outlook and prediction, which will be conducive to the realization of the individualized teaching, refined service and scientific management of ideological and political education in colleges and universities.

First of all, the content, method, process and other information of ideological and political education can realize the presentation of digitalization and visualization. Compared with the qualitative teaching method of ideological and political education in the past, a prominent advantage of big data is that it can make more accurate and visual measurement and presentation of the cognition, ideology, emotions and behaviors of the educatees that are difficult to quantify in the past, so that the ideological and political educators can master the situation of the ideological and political education objects more scientifically and carry out targeted education.

Secondly, the department of ideological and political education can master the state of ideological and political education and analyze the trend of ideological and political education through the data from big data analysis and research centers. Some colleges and universities have established big data research centers, for example, Tsinghua University has established "behavior and human data research laboratory", Chinese Academy of Sciences has established "cloud psychology laboratory", Shanghai Jiaotong University has established "big data engineering technology research center", University of Electronic Science and Technology of China has established "big data research center", which can better serve ideological and political education.

Finally, ideological and political educators can utilize big data analysis to provide individualized education services for college students. Ideological and political educators can carry out systematic empirical research on a certain phenomenon and a representative case, provide students with "customized" ideological and political education contents and methods, and provide scientific and effective guidance 
and reference for other ideological and political educators for college students.

\section{COUNTERMEASURES OF IDEOLOGICAL AND} POLITICAL EDUCATION IN COLLEGES AND UNIVERSITIES FROM THE PERSPECTIVE OF BIG DATA

\section{A. To Broaden the Collection Path of Big Data of Ideological and Political Education and Master Required Skills}

Big data has a huge volume and a fast growth rate; it has a wide range of sources, diverse characteristics, and complex data types and mode configurations. There are four main categories to obtain big data of ideological and political education in colleges and universities: campus website, including campus network, one-card platform, etc.; social media, such as micro blog, Wechat, forum, post bar, etc.; search engine; portal website, such as People.cn, Xinhua net, Sina, etc. The relevant departments of colleges and universities can adopt Hadhoop platform to process all kinds of structured and semi-structured data with the methods of virtualization and cloud computing, so as to obtain useful students' education information, but the difficulty lies in how to deal with unstructured data. For ideological and political educators, they must master the necessary computer knowledge to adapt to the requirements of data collection in the era of big data.

\section{B. To Establish Two Professional Teams for Big Data Technology Analysis and Practical Operation of Ideological and Political Education in Colleges and Universities, Establish Data Thinking and Improve the Level of Informatization}

Big data is closely related to computers. It is necessary to use computer technology comprehensively to acquire original data, screen and process data. For data collection and recognition, it involves character recognition, image recognition, speech recognition, language learning, etc.; for storage and processing, it includes distributed computing, cloud computing, etc. These originally scattered technologies need to be organically integrated into a system for application, and simple computer technology cannot solve the problems of what data shall be collected, stored, processed, and what programs and systems shall be designed. And yet data users are good at theory but not good at statistical measurement and not to mention computer technology, while computer technicians do not understand what data the users need for operation. Therefore, it is necessary to respectively establish two professional teams of big data collection, technical analysis and practical operation.

The big data technology teams shall be responsible for the top-level design and dynamic collection of the construction of campus data platform. At the same time, they shall adopt data mining to form the ranking list of social hot spots or students' concerns. In accordance with requirements, they shall adopt different algorithms and formulas to obtain the correlation between problems or different information. The application feedback teams of education and teaching include the theory course teachers, counselors, etc. of ideological and political education. They shall give feedback to the application effects and problems in time, and apply the statistical results of big data to the actual work. According to different problems, they can select different analysis methods, such as regression analysis method and neural network method. In particular, they can use visualization technology to transform the data into the description of ideological state. On the basis of grasping the development of ideological behavior of college students, they shall timely do a good job in the analysis, prediction and guidance of ideological dynamic of college students, and explore the law of ideological development of college students.

\section{To Establish Big Data Education Research Center and Build Comprehensive Auxiliary System for Ideological and Political Education Teaching in Colleges and Universities}

An Integrated information gathering platform should be built. One is to establish a systematic online data gathering platform by cooperating with the functional departments such as the library, office of academic affairs, office of students' affairs, college students' mental health consulting center, logistics service office, etc., to collect all kinds of data in the open Internet public sphere within the scope of laws and regulations permission and personal authorization; the other is to gather data in a targeted manner by special network questionnaire survey, network learning and communication that are offline organized by ideological and political education teachers, counselors and others to achieve the digitization of students' behavior and ideas and opinion expression, and effectively realize the ideological and political education under the big data mode. For example, before teaching, the ideological and political education workers shall first carry out the questionnaire survey on the education objects to understand the ideological status of students, the interest points, concerns and expectations of the course, and then carry out ideological and political education activities with a definite object in view. At the end of the course, the ideological and political education workers shall carry out the questionnaire survey and adjust the teaching contents and teaching methods through data comparison, so as to improve the effectiveness of ideological and political education.

\section{To Improve the Teaching of Ideological and Political \\ Theory Course in Colleges and Universities by Using the Characteristics of Big Data}

One of the advantages of the combination of big data technology and ideological and political theory course for college students is that it can use modern multimedia technology to carry out online teaching. Teachers can record teaching contents into short micro-videos so that students can complete video learning anytime and anywhere after class, then carry out "flip" in class, and then focus on the implementation of thematic discussion and troubleshooting. In the process of online teaching, teachers can constantly keep a watchful eye on the students' learning dynamics on the online platform, supervise the students' learning progress 
with the help of the system platform, and get after these students who lag behind the basic progress. Meanwhile, teachers can open the bullet screen teaching mode to strengthen the interaction between teachers and students. Teachers can determine where the students' learning difficulties are according to the information that students watch the video courses, so as to dynamically adjust the teaching contents and have a definite object in view. Although big data can release great value, the power of emotional teaching method of ideological and political educators cannot be replaced by online courses. Therefore, the combination of MOOC and traditional classroom is the ideal teaching mode of ideological and political theory course.

\section{CONCLUSION}

The coming of big data era brings not only challenges but also opportunities to the ideological and political education in colleges and universities. It requires us to actively cultivate big data ways of thinking, through the data collection, data analysis, education approach and other aspects to improve the effect of ideological and political education.

\section{REFERENCES}

[1] [British] Schoenberg V.M., Kenneth Cukier. Big Data Era [M]. Translated by Sheng Yangyan, Zhou Tao. Hangzhou: Zhejiang People'S Publishing House, 2013.

[2] Wang Sha, Yang Yang, et al. Review of Research on Big Data Ideological and Political Education [J]. University Education Science, 2015, (3). (in Chinese)

[3] Zhang Juan. Research on the Teaching Reform of Ideological and Political Theory Course in Colleges and Universities Based on Big Data [J]. Heilongjiang Higher Education Research, 2018, 36 (4). (in Chinese)

[4] Liu Hongda, Pan Kaiyan. Integrated Innovation: Perspective Conversion of Big Data Research in Ideological and Political Education [J]. School Party Building and Ideological Education, 2018 (3). (in Chinese) 